\title{
Podmioty ekonomii społecznej w procesie zarządzania innowacjami społecznymi
}

\author{
Dorota Moroń*, Monika Klimowicz**
}

\begin{abstract}
Streszczenie: Zmiany społeczne, potrzeby jednostek i rodzin oraz nasilające się problemy społeczne wywołują konieczność poszukiwania nowatorskich rozwiązań, które przyniosą korzyści społeczne, w sposób bardziej efektywny zaspokoją potrzeby i rozwiążą problemy społeczne. Innowacje społeczne nowe rozwiązania, generowane i wprowadzane bardzo często przez podmioty sektora społecznego - stanowią wyraz społecznej odpowiedzialności i przynoszą pozytywne efekty zarówno w skali mikro, jak i makrospołecznej. Celem artykułu jest zaprezentowanie modelu zarządzania innowacjami społecznymi, w którym główną rolę odgrywają podmioty sektora społecznego, zaliczane do ekonomii społecznej. W artykule wykorzystano metodę desk research, w ramach której dokonano analizy dokumentów unijnych, materiałów źródłowych oraz aktów prawnych. Przeprowadzone analizy wykazują różnorodność ujęć innowacji społecznych oraz ich odmienność od innowacji technologicznych. Specyficzny cykl życia innowacji społecznych wymaga określonego podejścia w zarządzaniu innowacjami społecznymi. W tym kontekście wskazać należy na podmioty sektora ekonomii społecznej, które jako struktury tworzone dobrowolnie, oddolnie, niezależnie od władz publicznych mają duże możliwości w zakresie wdrażania rozwiązań innowacyjnych.
\end{abstract}

Słowa kluczowe: innowacje społeczne, cykl życia innowacji, podmioty ekonomii społecznej, zarządzanie innowacjami społecznymi.

\section{Wprowadzenie}

Innowacje społeczne w sektorze ekonomii społecznej wynikają z wewnętrznej potrzeby człowieka lub grupy ludzi, a stanowiąc nowatorską formę osiągania celów pozwalają rozwiązywać problemy lepiej niż tradycyjne praktyki, jednocześnie - będąc wynikiem inicjatyw społecznych podejmowanych na poziomie lokalnym - pomagają zmieniać kierunek rozwoju społecznego. Mogą one dotyczyć społecznych procesów podejmowania aktywności lub realizować konkretny cel społeczny. Innowacje społeczne stanowią eksperymentalne działania społeczne mające na celu polepszenie jakości życia poszczególnych osób, grup społecznych, społeczności lokalnych, środowisk, a nawet społeczeństw.
Innowacje społeczne są efektem działań generowanych zarówno przez władze i sektor publiczny, przedsiębiorstwa i organizacje non-profit lub jako efekt współpracy między tymi sektorami. Podmioty reprezentujące różne sektory cechują się różnymi motywacjami

\section{* Dorota Moroń}

Zakład Polityki Społecznej i Ekonomicznej,

Wydział Nauk Społecznych

Uniwersytet Wrocławski

ul. Koszarowa 3, budynek 2/3, 51-149 Wrocław

e-mail: dorota.moron@uwr.edu.pl

\section{** Monika Klimowicz}

Katedra Studiów Europejskich, Wydział Nauk Społecznych

Uniwersytet Wrocławski

ul. Koszarowa 3, budynek 21, 51-149 Wrocław

e-mail: monika.klimowicz@uwr.edu.pl 
wdrażania rozwiązań o charakterze innowacyjnym. Decyduje więc o tym zysk ekonomiczny czy rachunek ekonomiczny (innowacje mogą w tańszy sposób prowadzić do osiągania celów), społeczna odpowiedzialność, chęć lepszej, bardziej profesjonalnej realizacji celów, efektywność w realizacji zadań, kreatywność w odpowiedzi na potrzeby społeczne. Każdy z sektorów - publiczny, rynkowy i non-profit ma swoją filozofię i zasady działania, każdy w oparciu o nie generuje i wdraża innowacje społeczne [Wiktorska-Święcka, Moroń, Klimowicz, 2015]. W artykule ograniczamy się do analizy innowacji społecznych w sektorze ekonomii społecznej i znaczenia tego sektora w rozwiązywaniu - dzięki innowacjom - problemów społecznych oraz realizacji ważnych, z perspektywy społecznej, zadań. Nie deprecjonujemy przy tym roli prywatnych przedsiębiorstw czy sektora publicznego jako obszarów tworzenia innowacji. Wszystkie sektory mają swój udział w kreowaniu innowacji, a ich współpraca może przynosić szczególne profity, dzięki wykorzystaniu mocny stron i zniwelowaniu ograniczeń w zakresie wynalazczości.

Innowacyjność prowadzi do zwiększenia umiejętności diagnozowania i rozwiązywania problemów z różnych dziedzin życia społecznego w sposób nowatorski. Staje się ona pochodną kształtowania otwartości na zmiany i umiejętności rozwiązywania problemów jako tych kompetencji, które sprzyjają wprowadzaniu nowych rozwiązań w obszarze rozwoju kapitału ludzkiego, a jednocześnie znajdują zastosowanie w różnych kontekstach zawodowych i społecznych.

Celem artykułu jest zaprezentowanie modelu zarządzania innowacjami społecznymi, w ramach którego główną rolę odgrywają podmioty sektora społecznego, zaliczane do sektora ekonomii społecznej. Artykuł jest efektem cząstkowych badań realizowanych $w$ ramach projektu badawczego Innovative Social Investment: Strengthening communities in Europe (InnoSI), finansowane- go z Ramowego programu Unii Europejskiej Horyzont 2020 w zakresie badań naukowych i innowacji. W artykule wykorzystano metodę desk research, w ramach której dokonano analizy dokumentów unijnych, materiałów źródłowych oraz aktów prawnych. Wyniki badań poddano krytycznej analizie, wykorzystując w tym celu dorobek polskiej i światowej literatury przedmiotu w zakresie zarządzania innowacjami społecznymi.

W artykule zaprezentowano kwestie definicyjne związane z innowacjami społecznymi, istotne ze względu na kontrowersje w zakresie rozumienia tego zjawiska oraz jego związku z innymi typami innowacji. Szczególny nacisk położono w tym zakresie na wykazanie - w aspekcie definicyjnym - powiązania innowacji społecznych i sektora ekonomii społecznej. Omówiono zarządzanie innowacjami społecznymi przez pryzmat ich cyklu życia, a także dla wykazania roli podmiotów sektora społecznego w tworzeniu i wdrażaniu innowacji społecznych przedstawiono model zarządzania innowacjami społecznymi, w którym główną rolę odgrywa sektor społeczny. Możliwości w zakresie wdrażania innowacji i zarządzania nimi w sektorze ekonomii społecznej zaprezentowano w kontekście cech charakterystycznych prawnych form przedsiębiorstw społecznych. Ich różnorodność umożliwia bowiem wybór takiej formuły, która ułatwia wdrażanie nowatorskich rozwiązań i daje szansę zarządzania organizacją w sposób preferowany przez twórców.

\section{Innowacje społeczne - ujęcie definicyjne}

Pojęcie innowacji społecznych ma krótką historię, ale długą przeszłość. Można powiedzieć, że stanowi nową kategorię w literaturze przedmiotu z zakresu zarządzania publicznego oraz polityk publicznych - upowszechniło się w niej w ostatnich dwudziestu latach. Nie oznacza to jednak, że wcześniej nie badano i nie analizowano zjawisk, które 
dziś określamy mianem innowacji społecznych. Innowacje o charakterze społecznym pojawiły się w pracach Petera Druckera oraz Michaela Young'a już w latach 60. XX wieku. Analiza takich zjawisk była również opisywana przez Pierre'a Rosanvallon, Jacquesa Fournier i Jacquesa Attali [Chambon, David, Devevey, 1982]. Niektórzy współcześni badacze zwracają nawet uwagę, iż temat i koncepcja dotycząca innowacji społecznych pojawiła się już dużo wcześniej, np. w pismach Benjamina Franklina, który mówił o małych modyfikacjach wewnątrz organizacji społecznej wspólnot, mogących pomóc w rozwiązywaniu codziennych problemów [Mumford, 2002, s. 253-266]. Warto również zaznaczyć, iż wielu XIX-wiecznych myślicieli, takich jak Robert Owen, założyciel ruch spółdzielczego, Max Weber czy Émile Durkheim skupiało uwagę na promowaniu nowatorskich rozwiązań w dziedzinie społecznej w ramach szerszych procesów społecznych [zob. Davies, Simon, 2013; BEPA, 2010, s. 23-24; BEPA, 2014, s. 17-19].

Jeden z pierwszych polskich badaczy innowacji społecznych, Witold Kwaśnicki, wskazuje, że w ujęciu podmiotowym geneza problematyki dotyczącej innowacji społecznych sięga początków cywilizacji ludzkiej, kiedy człowiek stał się istotą społeczną i zaczął funkcjonować $w$ relacjach społecznych [Kwaśnicki, 2014, s. 8]. Innowacje społeczne to szczególnego rodzaju zmiany generowane w otoczeniu społecznym, a będące wynikiem dążeń ludzi do realizacji ich zamierzeń, rozwiązywania problemów i podejmowania wyzwań. Innowacje społeczne są zjawiskiem dotyczącym różnych sektorów i branż, mogą być wdrażane zarówno przez podmioty formalne, jak i nieformalne, kształtowane przez inicjatywy trwale wpisane w istniejący kontekst instytucjonalny, jak i te powstające ad hoc dla zaspokojenia jednej, konkretnej potrzeby.

Wprowadzone do literatury naukowej pojęcie innowacji społecznych zostało zastosowane do opisu działań przedsiębiorstw spo- łecznych i przedsiębiorczości społecznej oraz innowacji technologicznych, które łącznie stanowią rozwiązanie innowacyjne, przynoszą korzyści społeczne oraz stanowią wyraz społecznej odpowiedzialności.

Kwerenda literatury naukowej prowadzi do wyróżnienia trzech sposobów definiowania innowacji społecznych [zob. WiktorskaŚwięcka, Moroń, Klimowicz, 2015, s. 23-31]. Nurt pierwszy koncentruje się na innowacjach innych niż techniczne w kontekście organizacyjnym, może być analizowany przez pryzmat zarządzania, choćby w zakresie wpływu kapitału społecznego na zwiększenie efektywności organizacyjnej [Moulaert et al., 2005, s. 1973-1974]. W tym kontekście innowacje społeczne obejmują np. dynamiczne zarządzanie, elastyczne organizacje, rozwój umiejętności i kompetencji czy tworzenie sieci między organizacjami [Pot, Vaas, 2008, s. 468], a także innowacje marketingowe [Kesselring, Leitner, 2008, s. 9]. Drugie ujęcie rozpatruje innowacje społeczne w kontekście współistnienia z innowacjami technologicznymi. Innowacje technologiczne są tu postrzegane jako symulator postępu społecznego, zaś innowacje społeczne są kluczowym czynnikiem dla powodzenia innowacji technicznych [Roth, 2009, s. 232; Howaldt, Schwarz, 2010, s. 28]. Nurt trzeci, najbliższy rozumieniu innowacji społecznych przez autorki artykułu, rozpatruje pojęcie innowacji społecznych jako niezależnych i nowych praktyk społecznych [Schmitt, 2014, s. 5-17]. Wyraźnie odróżnia ono innowacje technologiczne od społecznych, czyniąc z innowacji społecznych niezależny obszar badawczy.

Timo Hämäläinen i Risto Heiskala [2007] wyróżniają pięć rodzajów innowacji: technologiczne, ekonomiczne, regulujące, normatywne i kulturowe, przy czym podkreślają, że trzy ostatnie łącznie stanowią innowacje społeczne, ponieważ oddziałują na zasady, normy, wartości i świadomość społeczną. Innowacje społeczne określić można jako specyficzny, odmienny od innych typ inno- 
wacji - nowe rozwiązania, które prowadzą do konkretnych rezultatów [Caulier-Grice et al., 2012, s. 16].

Definiując innowacje społeczne, również w kontekście funkcjonowania podmiotów ekonomii społecznej, odwołać się można do efektów prac projektu „The theoretical, empirical and policy foundations for building social innovation in Europe" (TEPSIE), którego jednym z założeń było uporządkowanie wiedzy naukowej w tym zakresie. W przedsięwzięciu tym wskazano na pięć obszarów, w których przejawiają się innowacje społeczne. Po pierwsze, jest to proces transformacji społecznej, a innowacje dotyczą m.in. roli społeczeństwa obywatelskiego w procesie przemian społecznych, znaczenia ekonomii społecznej i przedsiębiorców społecznych w realizacji wzrostu gospodarczego i integracji społecznej, ale również roli biznesu w zmianie społecznej wyrażającej się w koncepcji społecznej odpowiedzialności biznesu. Po drugie, innowacje społeczne przejawiają się w modelu zarządzania organizacją, m.in. w zakresie budowania strategii biznesowych obejmujących zmiany w kapitałach: ludzkim, instytucjonalnym i społecznym, które prowadzą do poprawy sprawności organizacyjnej i poprawy konkurencyjności, również w instytucjach publicznych i podmiotach non-profit. Po trzecie, co szczególnie istotne $z$ perspektywy omawianej problematyki, innowacje społeczne odnoszą się do przedsiębiorczości społecznej, przede wszystkim w zakresie rozwoju nowych i innowacyjnych sposobów rozwiązywania problemów społecznych i odpowiadania na społeczne potrzeby poprzez zaangażowanie przedsiębiorców „wrażliwych społecznie”, prowadzących przedsiębiorstwa społeczne, a więc takie, które nacisk kładą na cele społeczne, a nadwyżki reinwestują. Po czwarte, innowacje społeczne dotyczą rozwoju nowych produktów, usług i programów, które efektywniej zaspokajają potrzeby społeczne. Dotyczą one usług publicznych, ale nie ozna- cza to, że mogą być świadczone wyłącznie przez sektor publiczny. Znacząca rola przypada tu również przedsiębiorstwom społecznym i organizacjom non-profit. Po piąte, innowacje społeczne dotyczą także modelu zarządzania, który można określić jako przejście w kierunku governance [The Young Foundation, 2012, s. 6-7].

Do kluczowych kryteriów, które pozwalają ocenić czy dane działanie jest innowacją społeczną zaliczyć należy:

- nowość - innowacje społeczne nie muszą być całkowicie oryginalne i wyjątkowe, wystarczy, że są nowe w danej dziedzinie, branży, regionie, rynku czy dla użytkownika albo są stosowane w nowy sposób;

- realizację w praktyce - a więc przejście schematu pomysł - realizacja. Działania innowacyjne muszą być implementowane w praktyce, a nie tylko stanowić konstrukt naukowy;

- skuteczność - innowacje społeczne powinny poprawiać wyniki m.in. w zakresie zaspokajania potrzeb, realizacji zamierzeń, jakości, satysfakcji, zmniejszenia kosztów;

- zaspokajanie potrzeb społecznych - nacisk na zaspokajanie potrzeb, realizację zamierzeń, a nie wyłącznie rozwiązywanie problemów społecznych;

- aktywizację - wspieranie zdolności społeczeństwa i poszczególnych kategorii społecznych do podejmowania działań społecznych [Moulaert, Nussbaumer, 2005; Sharra, Nyssens, 2010].

Analiza innowacji społecznych pozwala również na wskazanie, że innowacje są bardzo często działaniami międzysektorowymi - angażują wiele instytucji z różnych sektorów i osób w nich pracujących, ich tworzenie i wdrażanie zwykle wiąże się z koniecznością współpracy pomiędzy różnymi podmiotami [Dawson, Daniel, 2010]. Innowacje, co jest szczególnie widoczne w przypadku działań innowacyjnych przedsiębiorstw społecznych, bardzo często są działaniami oddolnymi, nierzadko w ich przypadku zaciera się granica pomiędzy produ- 
centem a konsumentem - użytkownicy stają się producentami (prosumentami), a odbiorcy usług polityki społecznej - aktywnymi kreatorami tej polityki (koproducentami). Innowacje społeczne przyczyniają się do lepszego wykorzystania kapitałów i zasobów, jak również, rozwijając zdolności beneficjentów, umożliwiają im zaspokojenie ich potrzeb w dłuższej perspektywie [Kwaśnicki 2014, s. 18-20].

Innowacjami społecznymi mogą być nowe produkty (np. technologie wspomagające osoby niepełnosprawne - syntezatory mowy, czytniki Braille'a), nowe usługi (np. bankowość mobilna), nowe procesy (np. crowdsourcing), nowe rynki (np. sprawiedliwy handel, banki czasu), nowe platformy nowe struktury prawne lub nowe platformy internetowe (np. Tyze.com - platforma która wspiera osoby starsze w dostępie do nieformalnych i formalnych form opieki), czy wreszcie nowe formy organizacyjne, takie jak firmy lub sieci (np. modele biznesowe Hub.New jako rodzaj franczyzy społecznej) [CaulierGrice et al., 2012].

Pojęcie innowacji społecznych, ze względu na wdrażanie rozwiązań innowacyjnych w praktyce polityki społecznej, zostało również zaadaptowane przez instytucje publiczne, w tym Unię Europejską, która rozwój innowacyjności, w tym innowacyjności społecznej, czyni jednym z głównych priorytetów Strategii Europa 2020. Unia Europejska wskazuje, że innowacje społeczne odpowiadają na potrzeby społeczne, szczególnie te, które nie są tradycyjnie zaspokajane przez sektor prywatny lub instytucje publiczne i są skierowane do słabszych grup w społeczeństwie [Europa 2020, 2010]. Docenia również wpływ innowacji społecznych na tworzenie nowych więzi społecznych i współpracy [Europa 2020, 2010]. Dodatkowo wskazuje, iż innowacyjne działania społecznie powinny być oparte na oryginalnym wykorzystaniu istniejących zasobów, mogą dotyczyć wykorzystania zarówno sprawdzonych już rozwiązań w odniesieniu do nowych grup społecznych lub obszaru działalności, jak i wypracowania prekursorskich, a nawet eksperymentalnych rozwiązań dla znanych, ale wciąż istotnych problemów [Europa 2020, 2010]. Innowacje społeczne powinny opierać się na „pomysłowości obywateli, organizacjach społeczeństwa obywatelskiego, społecznościach lokalnych, przedsiębiorcach i urzędnikach państwowych", dzięki czemu „produkty i usługi będą lepiej spełniać indywidualne, ale również zbiorowe aspiracje" [Guide to social innovation, 2013].

\section{Zarządzanie innowacjami społecznymi w ich cyklu życia}

Innowacje społeczne są bardziej złożone niż innowacje technologiczne czy produktowe. Prowadzi to do bardziej skomplikowanej struktury etapów cyklu życia innowacji społecznych i ma konsekwencje dla procesu zarządzania tymi innowacjami. W najbardziej znanej koncepcji cyklu życia innowacji społecznej Robina Murray'a, Julie Caulier-Grice oraz Geoffa Mulgana, zwraca się uwagę na ewolucję innowacji społecznej od zidentyfikowanej potrzeby aż do zmiany społecznej, jaką dana innowacja społeczna może wywołać. Graficznie prezentowana koncepcja wpisuje cykl życia innowacji społecznych w tzw. złotą spiralę, model ten zaprezentowano na rysunku 1.

Cykl życia innowacji społecznej obejmuje sześć ściśle powiązanych ze sobą etapów:

- identyfikowanie potrzeb (prompts) - rozpoznanie zapotrzebowania na innowację społeczną, identyfikacja nowych, niezaspokojonych lub niedostatecznie spełnionych potrzeb społecznych,

- generowanie idei (proposals) - tworzenie pomysłów odpowiadających na zidentyfikowane potrzeby społeczne,

- sprawdzenie innowacji w praktyce (prototyping) - pilotażowe wdrożenie innowacji oraz wprowadzenie ewentualnych udoskonaleń, ocena skuteczności nowych 


\section{Rysunek 1. Cykl życia innowacji społecznych}

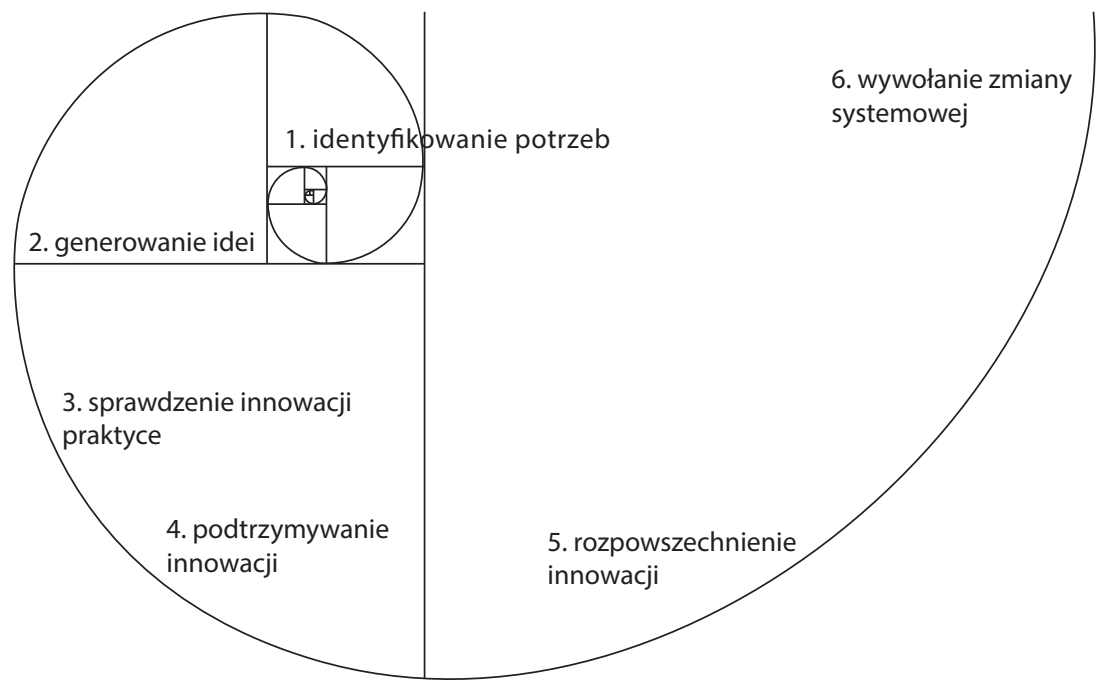

Źródło: [Murray, Caulier-Grice, Mulgan, 2010, s. 11].

rozwiązań w zaspokojeniu potrzeb społecznych,

- podtrzymywanie innowacji (sustaining) upowszechnienie innowacji, która okazała się wystarczająco dobra,

- rozpowszechnienie innowacji (scaling) zwiększenie zasięgu i wpływu innowacji społecznej,

- wywołanie zmiany systemowej (systemic change) - realizacja celu innowacji społecznej - wywarcie trwałej zmiany społecznej [Murray, Caulier-Grice, Mulgan, 2010, s. 12-13].

Przebieg etapów w cyklu życia innowacji społecznej wyznaczany jest przez zasadność i skuteczność nowego rozwiązania, które zostaje zaprezentowane jako odpowiedź na określoną potrzebę społeczną. Warto jednocześnie zwrócić uwagę, iż cykl życia innowacji społecznej ma charakter spiralny. Charakter ten wyraża założenie, iż rozpoczęcie działań innowacyjnych na poziomie mikro, dzięki zaangażowaniu wielu partnerów rozszerza się i przenosi na poziom makro. Skalowanie innowacji społecznej przez rozszerzane i misyjność przynosi w ostateczności korzyści co- raz większym grupom, prowadząc do trwałej zmiany systemowej, mogącej przeobrazić się w inwestycję społeczną.

Zarządzanie innowacjami społecznymi stanowi trudny i skomplikowany proces, doceniony najczęściej wówczas, gdy widoczne są już pozytywne jego efekty. Początkowe fazy, takie jak generowanie i wdrażanie innowacji społecznych, w przypadku sektora ekonomii społecznej wymagają społecznego zaangażowania jednostek oraz grup społecznych o wysokim poziomie kapitału ludzkiego, jak i społecznego. Zasady zarządzania są pochodną dwóch podstawowych typów innowacji: przełomowych i przyrostowych. Innowacje przyrostowe opierają się na poprawie jakości produktów lub usług dostępnych na rynku, poprawie sposobów produkcji czy zarządzania. Przełomowe innowacje społeczne wprowadzają natomiast zupełnie nowe produkty i usługi, bardziej efektywne lub rozwiązujące problemy wcześniej nierozwiązywalne lub trudne do rozwiązania [Christensen, 2003, s. 34]. Różnice między tymi innowacjami mają wpływ na proces 
zarządzania w ramach cyklu życia innowacji społecznej.

Skuteczne wdrażanie innowacji społecznych wymaga optymalnego zdiagnozowania problemu, na który odpowiedzą ma być niestosowane do tej pory rozwiązanie. W generowaniu i wdrażaniu innowacji społecznych w sektorze ekonomii społecznej ważne jest tworzenie nowych rozwiązań organizacyjnych oraz powiązań sieciowych między różnymi organizacjami i instytucjami dla realizacji celów lub projektów innowacyjnych. Nie oznacza to, że inwestycje społeczne nie mogą być tworzone i realizowane przez pojedyncze podmioty czy wręcz ich liderów. Sieci powiązań ułatwiają jednak realizację zadań, umożliwiając wykorzystanie zasobów (często w przypadku sektora ekonomii społecznej ograniczonych) różnych podmiotów.

Proces powstawania innowacji społecznych opiera się najczęściej na zewnętrznej presji lub negatywnym zjawisku zachodzącym w danej społeczności, które prowadzą do konieczności prowadzenia zmian w ustalonej konwencji postępowania. Do tworzenia innowacji społecznych przyczyniło się wykorzystanie metodologii projektowania, która wskazuje na wiele metod generowania innowacji, takich m.in. jak: mapowanie, open spa$c e$, targowisko pomysłów, design thinking, human centered design czy giełda rozwiązań [Brown, 2013; Kelley et al., 2015; Caulier-Grice et al., 2012]. Pamiętać jednocześnie należy, że innowacje społeczne mogą być działaniem zamierzonym, projektowanym, ale mogą też stanowić nieoczekiwany, serendypijny efekt współpracy oraz realizacji własnych możliwości rozwojowych [Klimowicz, 2011, s. 31].

\section{Znaczenie podmiotów sektora społecznego w tworzeniu i wdrażaniu innowacji społecznych}

Pomimo, iż innowacje społeczne pojawiają się i funkcjonują najczęściej w określonym kontekście instytucjonalnym, ich twórcami zawsze są konkretni ludzie, dlatego właśnie czynnik ludzki jest kluczowy w procesie powstawania, testowania i wdrażania innowacji społecznych. Zarządzanie innowacjami społecznymi w sektorze ekonomii społecznej musi być więc nakierowane na stworzenie ludziom - pracownikom, współpracownikom, wolontariuszom, członkom czy właścicielom możliwości tworzenia, testowania i wdrażania innowacji społecznych. Tworzenie innowacyjnych rozwiązań wymaga więc z jednej strony podjęcia działań na rzecz realizacji pomysłów, z drugiej - zebrania osób, które zbudują innowację. Struktury organizacyjne mogą w tym zakresie mieć działanie wspierające - ułatwiać organizowanie grup innowatorów, tworzenie projektów innowacyjnych, poszukiwanie współpracowników lub wręcz przeciwnie hamować działania o charakterze innowacyjnym, głównie poprzez sztywne wymogi i reguły działania pracowników.

Wprawdzie innowacje społeczne mogą być tworzone i wdrażane przez podmioty należące do sektora publicznego, jak i niepublicznego - przedsiębiorstwa rynkowe i organizacje pozarządowe, jednakże przy założeniu, że innowacje społeczne odpowiadają na potrzeby społeczne to zdecydowanie częściej innowacyjnymi rozwiązaniami zainteresowane będą podmioty zajmujące się rozwiązywaniem problemów społecznych czy świadczeniem usług społecznych, a więc instytucje publiczne i podmioty sektora ekonomii społecznej.

Z perspektywy instytucjonalnej większą łatwość kreowania i wdrażania rozwiązań innowacyjnych mają podmioty niepubliczne, szczególnie sektora ekonomii społecznej, nieograniczone sztywnymi zasadami działania, charakterystycznymi dla sektora publicznego. Kluczowe cechy podmiotów sektora ekonomii społecznej, do których zaliczyć można przede wszystkim prymat celów indywidualnych i społecznych nad kapitałem, dobrowolne i otwarte członkostwo, demokratyczną kontrolę sprawowaną przez członków, połą- 


\section{Rysunek 2. Model poczwórnej helisy a proces zarządzania innowacjami społecznymi, w którym główną rolę odgrywa sektor społeczny}

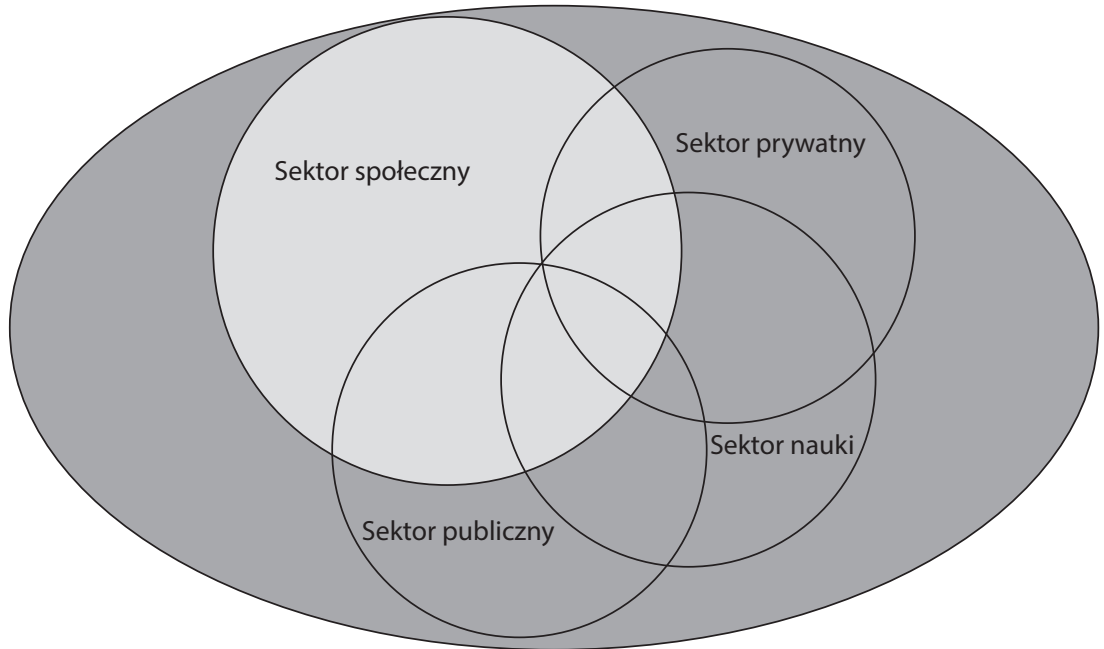

Źródło: opracowanie własne na podstawie: [Lindgren, Packendroff, 2010, s. 10].

czenie interesów członków, użytkowników i interesu ogólnego, rozwijanie i przyjmowanie wartości solidarności i odpowiedzialności, autonomiczne zarządzanie i niezależność od władz państwowych, przeznaczanie nadwyżek na stały rozwój celów i usług dla członków lub wspólnych zadań [Defourny, 2005, s. 63], sprzyjają generowaniu i wdrażaniu rozwiązań innowacyjnych.

Wdrażanie innowacji społecznych w partnerstwach opiera się na koncepcji poczwórnej helisy (quadruple helix), gdzie obok trzech sektorów: biznesowego, nauki i administracji, sytuuje się społeczeństwo obywatelskie. Model ten umiejscawia sektor obywatelski, w tym podmioty ekonomii społecznej, obok sektora publicznego, sektora nauki i biznesu, jako równoprawnego aktora kreowania procesów innowacyjnych [Arnkil et al., 2010]. W zależności zaś od usytuowania poszczególnych elementów, rodzaju innowacji, inicjatorów procesów innowacyjnych i odbiorców ich efektów, model ten może występować w różnych wariantach [Lindgren, Packendroff, 2010, s. 10]. W oparciu o powyższe założenia zaproponowano model zarzą- dzania innowacjami społecznymi, w ramach którego inicjatorem procesu są podmioty ekonomii społecznej. Został on zaprezentowany na rysunku 2.

Model zarządzania innowacjami społecznymi opiera się na zaangażowaniu sektora obywatelskiego, w tym sektora ekonomii społecznej, w ramach całego cyklu życia innowacji społecznej, od identyfikowania potrzeb, poprzez generowanie idei, sprawdzenie innowacji w praktyce, podtrzymywanie innowacji po rozpowszechnienie innowacji i wywołanie zmiany systemowej. Ze swej natury działanie takie musi zakładać aktywne uczestnictwo obywateli w rozwoju lokalnym i regionalnym oraz w realizacji idei społeczeństwa obywatelskiego. Należy przy tym pamiętać, że mówiąc o społeczeństwie obywatelskim uwzględnić trzeba zarówno podejście instytucjonalne, jak i czynniki endogenne, które mają wpływ na kształtowanie indywidualnych postaw obywatelskich, łączących się z pojęciem obywatelskości jednostki [Wiktorska-Święcka, 2009, s. 313-317]. „Obywatelskość” czyli „obywatelska postawa duchowa” lub „zbiorowa świadomość uczestnictwa” [Dahrendorf, 1994, s. 233] 
nie daje się ująć w formułę prawną i jest raczej sprawą demokratycznego obyczaju, niepisanej normy społecznej. Obywatelski typ postaw, poglądów i zachowań utożsamiany jest często z prospołecznym nastawieniem jednostek tworzących wspólnotę [WiktorskaŚwięcka, 2011, s. 80]. Jednocześnie obywatelskość stanowi podstawę budowania społeczeństwa obywatelskiego, które tworzą obywatele w celu realizacji swoich interesów lub uzyskiwania poparcia dla wyznawanych przez siebie idei. Cechą charakteryzującą społeczeństwo obywatelskie jest partycypacyjne zarządzanie otwierające możliwość pojawiania się różnych form partycypacji społecznej: od działań zorientowanych na dążenie do konsensusu, poprzez doprowadzenie i dopuszczenie do debaty publicznej, do uzyskania prawa do opozycji wobec działań władz publicznych, aż po bezpośredni udział w decyzjach natury administracyjnej i/lub politycznej oraz w działaniach na rzecz zaspokajania potrzeb własnych i członków społeczności [Wiktorska-Święcka, 2011, s. 82]. W kontekście tworzenia środowiska dla innowacji społecznych, najbardziej efektywną formą partycypacji społecznej jest partnerstwo, w ramach którego obywatele zaangażowani są wraz z przedstawicielami pozostałych sektorów we wspólne diagnozowanie potrzeb oraz problemów społecznych, planowanie sposobu ich zaspokojenia i/lub rozwiązywania oraz generowanie rozwiązań, a także ich wdrażanie.

Dla porównania, model generowania i wdrażania innowacji społecznych, w którym główną rolę odgrywa sektor prywatny wymaga ustanowienia wzajemnych powiązań zarówno między pracownikami i przedsiębiorstwem, jak i z otoczeniem. Istnienie wzajemnych relacji powoduje w następstwie konieczność zapewnienia skutecznych narzędzi i mechanizmów, które pozwalają generować i wdrażać innowacje społeczne zarówno w przedsiębiorstwie, jak i w całym układzie. Innowacje społeczne w przedsiębiorstwach są często traktowane jako jeden z wymia- rów działań podejmowanych w ramach CSR ${ }^{1}$. W szerszym kontekście tworzenie środowiska dla innowacji społecznych umiejscawia działalność przedsiębiorstw w koncepcji „,korporacyjnego obywatelstwa" (corporate citizenship). Jest to obszar możliwej współpracy sektora prywatnego z organizacjami społecznymi, w ramach którego łącząc zagadnienia związane $z$ efektywnością gospodarczą oraz demokracją uczestniczącą, podnosi rolę, jaką w przedsiębiorstwie, jak również w środowisku lokalnym, odgrywa jednostka wraz ze swoim potencjałem, lecz również jej potrzeby oraz problemy.

W przypadku modelu zarządzania innowacjami społecznymi, w ramach którego główną rolę odgrywa sektor nauki, zadaniem instytucji badawczych i naukowych jest generowanie sposobów pozyskiwania wiedzy na temat innowacji społecznych, kumulowanie i przetwarzanie wiedzy dotyczącej innowacji społecznych oraz przystosowanie wyników badań do ich praktycznej implementacji, a także upowszechnianie innowacji społecznych. Wówczas zaangażowanie podmiotów ekonomii społecznej powinno koncentrować się na współpracy z ośrodkami naukowo-badawczymi dotyczącej diagnozowania potrzeb i problemów społecznych. Jednocześnie warto zaznaczyć, że nieodzownym źródłem innowacji społecznych jest transfer wiedzy z sektora nauki do sektora publicznego, prywatnego oraz społecznego. Transfer ten wiąże się z przystosowaniem wyników badań naukowych do praktycznego ich wykorzystania w administracji, biznesie lub społeczeństwie. Podmioty ekonomii społecznej w ramach współpracy z jednostkami badawczo-rozwojowymi mogą zatem uczestniczyć we wdrażaniu i transferowaniu innowacji społecznych

\footnotetext{
Warto zwrócić uwagę na intensywny rozwoju teorii wskazujących na szczególną rolę współczesnych przedsiębiorstw w kreowaniu wartości społecznej oraz innowacji społecznych (np. teoria CSV - Creating Shared Value - opracowana przez M. E. Portera i M. R. Kramera, czy teoria Firmy - Idei, autorstwa J. Hausnera i M. Zmyślonego).
} 
na linii nauka-administracja, nauka-biznes czy nauka-społeczeństwo.

Warto zwrócić uwagę na znaczenie podmiotów ekonomii społecznej w modelu generowania i wdrażania innowacji społecznych, w którym główną rolę odgrywa sektor publiczny. Mamy w tym zakresie do czynienia z wprowadzaniem takich rozwiązań prawnych, organizacyjnych i finansowych, których zadaniem jest budowanie środowiska sprzyjającego twórczym i kreatywnym rozwiązaniom w obszarze społecznym. Podmioty ekonomii społecznej mogą w ramach tego modelu wdrażać innowacje społeczne w oparciu o finansowane ze środków publicznych programy promujące innowacje społeczne czy rozwiązania prawne sprzyjające rozwijaniu alternatywnych form organizacyjnych, takich jak: klastry innowacji społecznych, przedsiębiorczość społeczna czy żywe laboratoria.

Wspieranie ekonomii społecznej, w wymiarze podnoszenia możliwości generowania i wdrażania innowacji społecznych, stało się jednym z najważniejszych elementów polityki Unii Europejskiej wobec tego sektora. Rosnące znaczenie sektora ekonomii społecznej w Unii Europejskiej przyczyniło się do uruchomienia programów oraz linii finansowych przeznaczonych dla podmiotów ukierunkowanych na osiąganie celów społecznych. W styczniu 2013 r. Komisja Europejska, wskazując istotną rolę jaką odgrywają przedsiębiorcy społeczni w Strategii Europa 2020, uznała, iż podmioty ekonomii społecznej, w szczególności zaś przedsiębiorstwa społeczne, są istotnymi czynnikami napędzającymi tworzenie miejsc pracy i rozwiązań sprzyjających włączeniu społecznemu [Plan działania na rzecz..., 2012].

Partycypacja podmiotów gospodarki społecznej w realizacji różnych zadań publicznych łączy w sobie nie tylko możliwość wielosektorowej realizacji zadań, lecz również osiągania celów dodatkowych, które stanowią istotny element rozwoju społeczno-go- spodarczego, takich jak rozwój kapitału społecznego czy innowacyjności społecznej [Klimowicz, 2014, s. 172]. Warto zaznaczyć, że działalność wielu podmiotów ekonomii społecznej ze swej natury wydaje się być zdecydowanie bardziej innowacyjna, gdyż z konieczności organizacje te, aby rozwiązywać problemy społeczne, poszukują niekonwencjonalnych, nowatorskich i niestosowanych dotychczas rozwiązań.

\section{Forma prawna podmiotów ekonomii społecznej jako czynnik stymulujący innowacyjność społeczną}

Innowacyjność podmiotów sektora ekonomii społecznej wynika z jednej strony z faktycznej potrzeby możliwie najlepszego działania w sferze społecznej, efektywnego zaspokajania potrzeb i rozwiązywania problemów, z drugiej zaś z faktu, że ich prawna konstrukcja obejmująca samorządność, niezależność, otwartość na ludzi, możliwość pozyskiwania środków z różnych źródel, jest elementem stymulującym i wspierającym generowanie rozwiązań innowacyjnych. Oddolne tworzenie i kolektywne zarządzanie podmiotami sektora ekonomii społecznej sprzyja uaktywnieniu kapitału ludzkiego i społecznego, a co za tym idzie wspomaga innowacyjność. Podkreślić należy, że przedsiębiorstwa społeczne przyjmować mogą różne - odmienne od siebie - formuły prawne, które w sposób najlepszy będą odpowiadały potrzebom ich twórców.

Szczególnie często nowatorskie rozwiązania konstruują stowarzyszenia i fundacje - najbardziej popularne formy prawne sektora pozarządowego w Polsce. Rolę taką pełnić mogą również spółdzielnie socjalne oraz spółki działające na zasadach non-profit, jak i inne przedsiębiorstwa społeczne, a więc podmioty gospodarcze, których działalność ma cele społeczne [Moroń, 2012a; Moroń, 2012b; Wiktorska-Święcka, Moroń, Klimowicz, 
2015]. Cele społeczne w przypadku niektórych typów podmiotów uzupełniane są celami zarobkowymi, co pozwala łączyć różne priorytety działań innowacyjnych. W tabeli 1 przedstawiono kluczowe informacje dotyczące prawnych form podmiotów sektora ekonomii społecznej predystynowanych do generowania i wdrażania innowacji społecznych. Różnorodna oferta w zakresie form prawnych w sektorze ekonomii społecznej pozwala na wybór formuły działań najlepiej dostosowanych do celów i preferowanych sposobów działania.

Innowacyjność podmiotów sektora ekonomii społecznej wynika z nastawienia na chęć jak najlepszego działania w sferze społecznej, efektywnego rozwiązywania problemów, dużą zaletą jest tu - w odróżnieniu od sektora publicznego - samorządność i niezależność. Podmioty samodzielnie określają i podejmują decyzje, różnorodność form prawnych pozwala na wybór działań bardziej kolektywnych (np. w stowarzyszeniach czy spółdzielniach) lub liderskich (w przypadku fundacji).

Możliwość pozyskiwania środków z różnych źródeł, w tym ze składek członkowskich, z ofiarności publicznej, czy z działalności gospodarczej pozwala na dywersyfikację dochodów, ułatwia działania i uniezależnia od biurokratycznych zasad i procedur, chociaż często (pomimo tak wielu możliwości zdobywania funduszy) rodzi problemy związane z niedostatkiem środków finansowych lub uzależnieniem od wsparcia ze strony instytucji publicznych [Arczewska 2011; Przewłocka et al., 2012]. Z kolei nacisk na działalność gospodarczą może upodobnić podmioty sektora ekonomii społecznej do prywatnych przedsiębiorstw. Koszty działań obniża możliwość korzystania z pracy społecznej członków i wolontariuszy.

Podmioty sektora ekonomii społecznej, szczególnie spółdzielnie, ale również stowarzyszenia, często działają na rzecz swoich twórców i członków, stąd ich zaangażowa- nie w aktywność jest większe niż w przypadku jednostek administracji. Istnieje tu jednak również zagrożenie, że skupiając się na realizacji własnych celów liderzy podmiotów sektora ekonomii społecznej w mniejszym stopniu realizować będą zadania społeczne.

Dużą rolę w formułowaniu i wdrażaniu rozwiązań innowacyjnych stanowią też partnerstwa, będące swoistą formułą współpracy kilku (czy nawet kilkunastu) podmiotów należących do jednego lub kilku sektorów: publicznego, pozarządowego i rynkowego. Współpraca podmiotów sektora ekonomii społecznej rozwija się z jednej strony w związku z wzajemną sympatią i zamiarem wspólnej realizacji celów, z drugiej jednak często wymusza ją brak środków finansowych, konieczność połączenia sił w kontaktach $z$ administracją publiczną czy zjednoczenia działań dla realizacji wspólnych projektów. Niezależnie od tego czy współdziałanie wynika z preferencji organizacji, czy jest niejako wymuszone okolicznościami zewnętrznymi, wspólne działania często są bardziej efektywne niż praca tylko jednej organizacji. Dla potrzeb współpracy podmioty tworzą nieformalne sieci lub koalicje, formalizują współpracę na potrzeby konkretnych działań (np. w formie porozumień), ale tworzą też federacje, a więc podmioty o sformalizowanej strukturze, zasadach funkcjonowania i zadaniach. Federacje to nic innego jak związki stowarzyszeń, działające na podstawie ustawy Prawo o stowarzyszeniach, chociaż w praktyce przyjmują różne nazwy, np. federacja, związek, wspólnota, partnerstwo, forum. Do związku stowarzyszeń należeć muszą minimum trzy stowarzyszenia, członkami mogą być także inne osoby prawne, np. fundacje czy organizacje kościelne. Związek stowarzyszeń podlega rejestracji w KRS, co czyni go odrębną od tworzących go organizacji formalną strukturą, mającą własne cele i sposoby ich realizacji, majątek i możliwości prowadzenia działań. Innym sposobem na partnerstwo organizacji pozarządowych może być wspólne powołanie fundacji. 


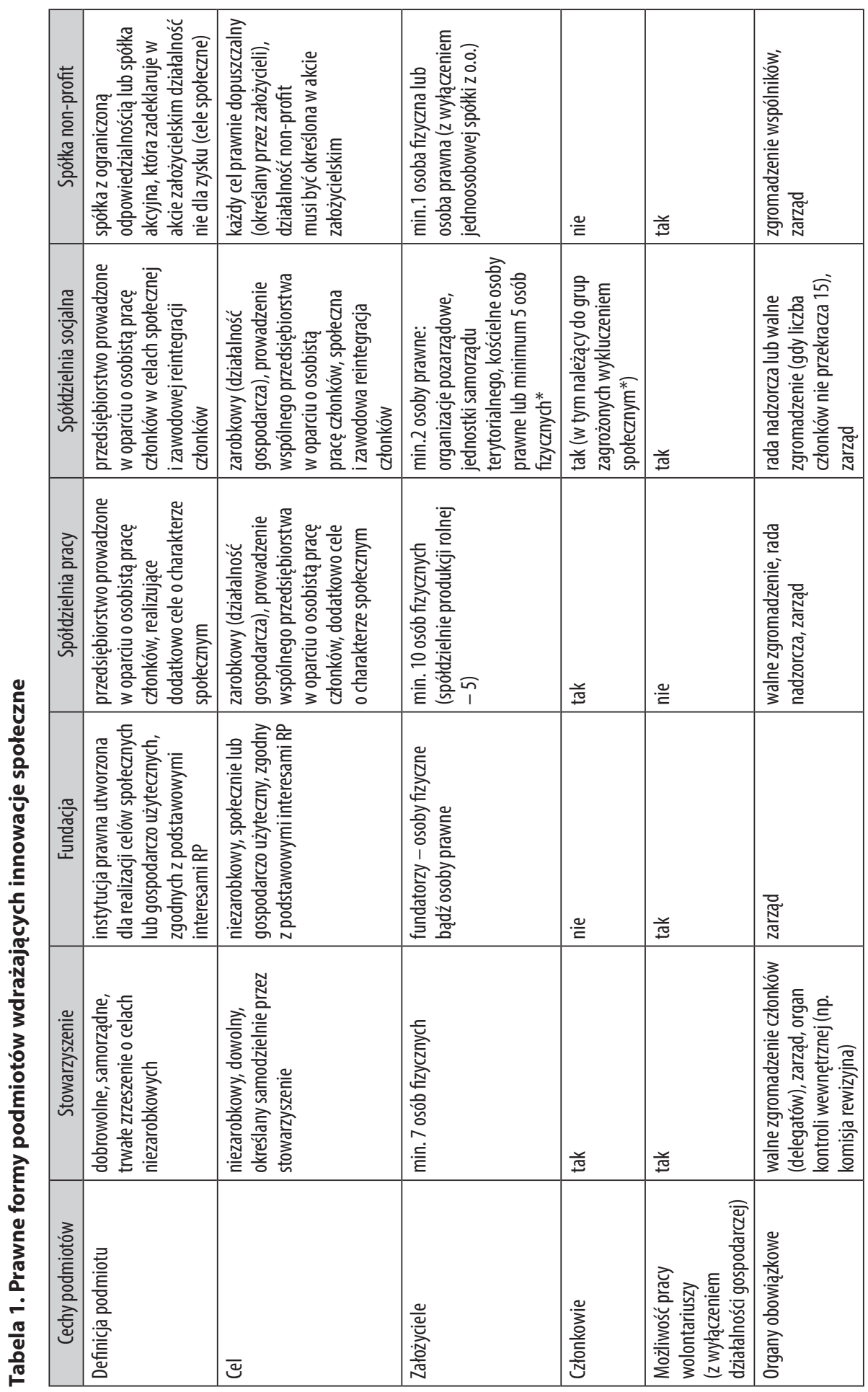




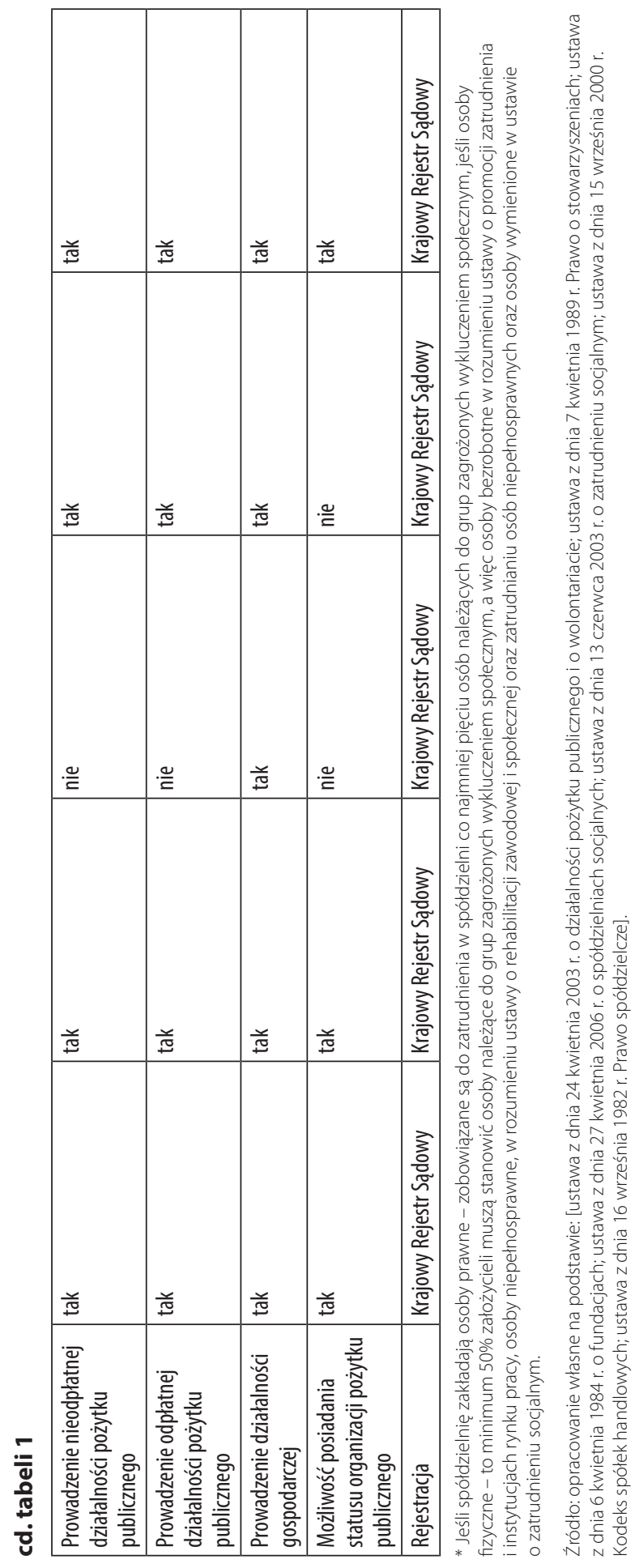


Partnerstwa lokalne są natomiast formułą umożliwiającą zaangażowanie się wszystkich podmiotów zainteresowanych działalnością na rzecz dobra wspólnoty lokalnej. Mają być one płaszczyzną współdziałania organizacji pozarządowych, samorządu terytorialnego, prywatnych firm, a także nieformalnych grup i osób indywidualnych, a więc łączyć podmioty z różnych sektorów. Partnerstwa lokalne mogą funkcjonować jako inicjatywy nieformalne, formalne porozumienia tworzone dla realizacji konkretnego zadania oraz jako partnerstwa sformalizowane. Partnerstwa szczególnie takie, które łączą podmioty publiczne i organizacje pozarządowe (a także przedsiębiorstwa prywatne) są niezwykle istotne dla kreowania i wdrażania innowacji społecznych. Wynika to z dwóch powodów. Po pierwsze, formuła współpracy pozwala na wykorzystanie silnych stron wszystkich zaangażowanych podmiotów - daje szansę na połączenie np. innowacyjnych pomysłów organizacji pozarządowych z wiedzą, doświadczeniem i zapleczem organizacyjno-finansowym instytucji publicznych. Konfrontacja różnych wizji, sposobów rozwiązywania problemów i świadczenia usług, sprzyja zarówno konstruowaniu nowatorskich rozwiązań, jak i ich wstępnej weryfikacji. Po drugie, bardzo często korzystanie z funduszy na wsparcie innowacyjnych rozwiązań wymaga tworzenia konsorcjów. Wzajemna współpraca jest więc w wielu przypadkach warunkiem uzyskania środków na działalność innowacyjną.

Istotne znaczenie dla tworzenia innowacji społecznych ma kondycja sektora pozarządowego. W literaturze przedmiotu szczególne znaczenie przypisuje się tu przedsiębiorczości społecznej, która sama w sobie stanowi przejaw innowacji społecznych zarówno w sferze gospodarczej, jak i społecznej. Dane statystyczne wskazują, że gospodarka społeczna w ciągu ostatnich kilku dziesięcioleci stała się znaczącym sektorem tworzącym nowe miejsca pracy, wprowadzającym innowacyjne rozwiązania w dziedzi- nie zarządzania i realizującym cele społeczne przy jednoczesnej realizacji celów gospodarczych [Klimowicz 2014, s. 207]. Podmioty gospodarki społecznej i przedsiębiorstwa społeczne są bowiem traktowane jako istotny czynnik napędzający tworzenie miejsc pracy i innowacje społeczne sprzyjające włączeniu społecznemu [Plan działania na rzecz..., 2013, s. 5]. Przedsiębiorcy społeczni są zarazem postrzegani jako innowatorzy społeczni. Potencjał innowacyjny podmiotów gospodarki społecznej jest wyraźnie widoczny zarówno w formach organizacyjnych, jak i działalności łączącej realizację celów społecznych z celami gospodarczymi. Innowacyjny model zarządzania podmiotami gospodarki społecznej, zwiększający uczestnictwo i gwarantujący demokratyczny sposób podejmowania decyzji, wzmacniający zaangażowanie jej pracowników w sprawy przedsiębiorstwa, będące wynikiem wspólnej odpowiedzialności, doprowadził do powstania w sektorze wielu innowacyjnych rozwiązań. Warto chociażby wspomnieć tu o rozwijającej się w sektorze finansowym bankowości etycznej, czy mikrokredytach, które niosą za sobą widoczne zmiany społeczne, zarówno w obszarze inkluzji społecznej, jak również inkluzji finansowej.

Dyfuzja innowacji społecznych (zarówno pod względem geograficznym i liczby zaangażowanych podmiotów) zależy od istniejących ram instytucjonalno-organizacyjnych i możliwości jej adaptacji. To, czy dana innowacja społeczna będzie miała szerszy wpływ na społeczeństwo, uzależnione jest w dużej mierze od interakcji między czynnikami politycznymi, społecznymi, ekonomicznymi i kulturowymi [Westley, Antadze, 2010, s. 14]. Dyfuzja innowacji społecznych wymaga bowiem współdziałania różnych sektorów, gdyż bez tego nie da się uzyskać pożądanego efektu synergii będącego istotnym czynnikiem zwiększającym możliwość adaptacji innowacji społecznej oraz jej implementacji w nowych warunkach. 


\section{Podsumowanie}

Działalność podmiotów ekonomii społecznej nierozerwalnie związana jest z innowacyjnością społeczną, co sprawia, że sektor społeczny jest ważnym obszarem generowania i wdrażania rozwiązań innowacyjnych. Niejednokrotnie bowiem przedsiębiorstwa społeczne spotykają się z koniecznością rozwiązywania problemów społecznych w sytuacjach, które stanowią naturalne źródło innowacji społecznych. Mogą do nich należeć nieoczekiwane zmiany, takie jak: katastrofy i klęski żywiołowe, zmiany klimatu, zatrucie środowiska naturalnego, gwałtowna urbanizacja, nadmierna eksploatacja zasobów naturalnych, modyfikacja sytuacji geopolitycznej, zmiany demograficzne, w tym starzenie się ludności, zmiany modelu rodziny i życia społecznego oraz epidemie i ubóstwo, czy konflikty i napięcia międzykulturowe (np. nietolerancja, nierówności religijne, rasowe i płciowe). Obszary te stanowią pola działalności podmiotów ekonomii społecznej, a przekształcenia i nowe wyzwania pozwalają na kreowanie rozwiązań innowacyjnych.

Nie tylko zmiana i chęć rozwiązywania problemów społecznych przyczynia się do kreowania społecznych innowacji. Podmioty sektora ekonomii społecznej często powstają dla zaspokojenia potrzeb obywateli, a innowacyjne pomysły dotyczą właśnie rozwiązań, które w sposób lepszy, bardziej efektywny odpowiadają na wymogi i oczekiwania jednostek oraz rodzin. Sytuacje zmian, problemów społecznych czy potrzeb same w sobie nie

\section{Literatura}

Arczewska M. (2011). Obszary działań i interwencji stycznych dla jednostek samorzadu terytorialnego i instytucji ekonomii społecznej (organizacji pozarzadowych). Raport z badania. Warszawa: Wrzos, http:// www.wrzos.org.pl/download/Raport\%20TORO_ WRZOS.pdf.

Arnkil R., Järvensivu A., Koski P., Piirainen T. (2010). Exploring the Quadruple Helix. Report of Quadruple Helix. stanowią źródła innowacji społecznych, tworzą natomiast podłoże ich pojawienia się, pod warunkiem istnienia odpowiednich sprzyjających warunków do podejmowania kreatywnych, niekonwencjonalnych i twórczych działań mających na celu poszukiwanie nowatorskich rozwiązań.

Prawna konstrukcja podmiotów ekonomii społecznych stanowi czynnik ułatwiający społeczną innowacyjność. Samorządność, niezależność, brak utartych reguł i szczegółowo określonych zasad działania, możliwość nieskrępowanego wyrażania poglądów i realizacji pomysłów ułatwia kreowanie innowacyjnych rozwiązań. Przedsiębiorstwa społeczne są miejscem dla tych, którzy nie godzą się na klasyczne, powielane metody pracy, ale szukają innych dróg osiągnięcia celu.

Sektor ekonomii społecznej stanowi więc naturalny obszar generowania innowacyjnych pomysłów, przede wszystkim w mikroskali. Sprawdzone rozwiązania mogą być rozpowszechniane i - jak wskazuje cykl życia innowacji społecznej - prowadzić do zmian systemowych. Dlatego istotne jest, aby w procesie generowania i wdrażania innowacji społecznych podmioty ekonomii społecznej natrafiały na środowisko sprzyjające myśleniu innowacyjnemu oraz ułatwiające upowszechnianie sprawdzonych innowacyjnych rozwiązań. Te zadania przypisane powinny być sektorowi publicznemu, który dzięki możliwościom formalno-organizacyjnym sprzyjać powinien współpracy na rzecz innowacji społecznych.

Research For the CLIQ Project, Co-Financed by European Regional Development Fund INTERREG IVC Programme, Work Research Centre University of Tampere. BEPA (2010). Empowering people, driving change: Social innovation in the European Union. Bureau of European Policy Advisors, http://ec.europa.eu/ewsi/ UDRW/images/items/docl_17731_35611801.pdf (dostęp: 12.11.2015).

BEPA (2014). Social Innovation. A Decade of Changes. A BEPA report. Bureau of European Policy Advisors, 
http://espas.eu/orbis/sites/default/files/generated/ document/en/social_innovation_decade_of_changes.pdf (dostęp: 12.11.2015).

Brown T. (2013). Zmiana przez design: jak design thinking zmienia organizacje i pobudza innowacyjność. Warszawa: Wydawnictwo Libron.

Caulier-Grice J., Davies A., Patrick R., Norman W. (2012). Defining Social Innovation. A deliverable of the project: The theoretical, empirical and policy foundations for building social innovation in Europe (TEPSIE), Brussels: European Commission, DG Research.

Chambon J.L., David A., Devevey J.M. (1982). Les Innovations Sociales. Paris: Presses Universitaires de France.

Christensen C.M. (2003). The innovator's dilemma: When new technologies cause great firms to fail. Harvard: Harvard Business Press.

Dahrendorf R. (1994). „Co zagraża społeczeństwu obywatelskiemu", w: K. Michalski (red.), Europa i spoteczeństwo obywatelskie. Rozmowy z Castel Gandolfo. Kraków: Wydawnictwo Znak.

Dawson P., Daniel L. (2010). „Understanding social innovation: A provisional framework", International Journal of Technology Management, 51(1).

Defourny J. (2005). „Przedsiębiorstwo społeczne w poszerzonej Europie: koncepcja i rzeczywistość, w: Ekonomia społeczna Kraków 2004: II Europejska Konferencja Ekonomii Społecznej: materiały. Warszawa: Ministerstwo Polityki Społecznej.

Europa 2020. Strategia na rzecz inteligentnego i zrównoważonego rozwoju sprzyjającego włączeniu społecznemu (2010). Bruksela: Komisja Europejska.

Guide to social innovation (2013). Brussels: European Commission, http://s3platform.jrc.ec.europa. eu/documents/10157/47822/Guide\%20to\%20Social\%20Innovation.pdf (dostęp: 07.11.2015).

Hämäläinen T., Heiskala R. (2007). Social Innovations, Institutional Change and Economic Performance: Making Sense of Structural Adjustment Processes in Industrial Sectors, Regions and Societies. Cheltenham: Edward Elgar Publishing.

Howalt J., Schwarz M. (2010). Social innovation: concepts, research fields and international trends. Dortmund: Sozialforschungsstelle.

Kelley D., Kelley T. (2015). Twórcza odwaga. Warszawa: Wydawnictwo MTBiznes.

Kesselring A., Leitner M. (2008). Soziale Innovationen in Unternehmen. Study. Wien: Zentrum für Soziale Innovationen.

Klimowicz M. (2011). „Innowacje społeczne jako serendypny efekt wzrostu kapitału ludzkiego", w: Grabowiec P., Klimowicz M. (red.), Człowiek we współczesnej gospodarce globalnej. Wrocław: Wydawnictwo Wyższej Szkoły Zarządzania i Finansów we Wrocławiu. Klimowicz M. (2014). „Przedsiębiorstwa społeczne jako instrument aktywnej polityki rynku pracy w Unii Europejskiej", w: Kubiak M. (red.), Polityka społeczna wobec wyzwań i zmian zachodzących we współcze- snym świecie. Gdańsk-Radom: Uniwersytet Gdański-UTH.

Kwaśnicki W. (2014). „Innowacje społeczne - nowy paradygmat czy kolejny etap w rozwoju kreatywności człowieka?", w: Misztal W., Chimiak G., Kościański A. (red.), Obywatelskość wobec kryzysu: uśpieni czy innowatorzy? Warszawa: IFiS PAN.

Lindgren M., Packendroff J. (2010). „The role of NGOs in supporting women's entrepreneurship. A study of a Quadruple Helix project in the Baltic Sea region", Quadruple Helix Reports, nr 4.

Moroń D. (2012a). „Specyfika zarządzania kapitałem ludzkim i społecznym w trzecim sektorze", w: Moroń D. (red.), Kapitał ludzki i społeczny. Kreowanie i zarzqdzanie. Wrocław: Wydawnictwo Uniwersytetu Wrocławskiego.

Moroń D. (2012b). Organizacje pozarzadowe - fundament społeczeństwa obywatelskiego. Wrocław: Wydawnictwo Uniwersytetu Wrocławskiego.

Moulaert F. et al. (2005). „Towards alternative modeI(s) of local innovation", Urban Studies, 42 (11).

Moulaert F., Nussbaumer J. (2005).,The social region: beyond the territorial dynamics of the learning economy", European Urban and Regional Studies, nr 12 (1).

Mumford M.D. (2002), "Social Innovation: Ten Cases from Benjamin Franklin", Creativity Research Journal, nr 14 (2).

Murray R., Caulier-Grice J., Mulgan G. (2010). The open book of social innovaiton, Social Innovator Series. London: NESTA.

Plan działania na rzecz przedsiębiorczości do 2020 r. Pobudzanie ducha w Europie, COM (2012) 795/ 2013. Komunikat Komisji do Parlamentu Europejskiego, Rady, Europejskiego Komitetu Ekonomiczno-Społecznego i Komitetu Regionów.

Pot F., Vaas F. (2008). "Social innovation, the new challenge for Europe", International Journal of Productivity and Performance Management, nr 57 (6).

Przewłocka J., Adamiak P., Herbst J. (2012). Podstawowe fakty o organizacjach pozarzadowych. Raport z badania 2012, Warszawa: Stowarzyszenie Klon/Jawor, http://www.ngo.pl/PodstawoweFakty_2012_raport/ebook/content/PodstawoweFaktyNGO_2012_ KlonJawor_raport.pdf.

Roth S. (2009). Neu für wen? Erste Aufnahmen aus der Sozialdimension der Innovationen. Bern: Fachhochschule.

Schmitt J. (2014). Social Innovation for Business Success. Shared Value in the Apparel Industry. Wiesbaden-Berlin: Heidelberg-Springer.

Sharra R., Nyssens M. (2010). Social Innovation: An Interdisciplinary and Critical Review of the Concept. Louvain: Université Catholique de Louvain.

TEPSIE (2014). Building the Social Innovation Ecosystem. A deliverable of the project: "The theoretical, empirical and policy foundations for building social innovation in Europe" (TEPSIE), European Commission - 7th Framework Programme, Brussels: European Commission, DG Research. 
The Young Foundation (2012). Social Innovation Overview - Part I: Defining social innovation. A deliverable of the project: "The theoretical, empirical and policy foundations for building social innovation in Europe" (TEPSIE), European Commission - 7th Framework Programme, Brussels: European Commission, DG Research, http://www.tepsie.eu/images/documents/TEPSIE.D1.1.Report.DefiningSociallnnovation. Part\%201\%20-\%20defining\%20social\%20innovation. pdf (dostęp: 12.11.2015).

Ustawa z dnia 13 czerwca 2003 r. o zatrudnieniu socjalnym, Dz.U. z 2011 r., nr 43, poz. 225, tekst jednolity ze zm.

Ustawa z dnia 15 września 2000 r. Kodeks spółek handlowych, Dz.U. z 2013 r., poz. 1030, tekst jednolity ze zm.

Ustawa z dnia 16 września 1982 r. Prawo spółdzielcze, Dz.U. z 2013 r., poz. 1443, tekst jednolity ze zm.

Ustawa z dnia 24 kwietnia 2003 r. o działalności pożytku publicznego i o wolontariacie, Dz.U. z 2014 r., poz. 1118, tekst jednolity ze zm.

Ustawa z dnia 27 kwietnia 2006 r. o spółdzielniach socjalnych, Dz.U. z 2006 r., nr 94, poz. 651, tekst jednolity ze zm.
Ustawa z dnia 6 kwietnia 1984 r. o fundacjach, Dz.U. z 1991 r., nr 46, poz. 203, tekst jednolity ze zm.

Ustawa z dnia 7 kwietnia 1989 r. Prawo o stowarzyszeniach, Dz.U. z 2001 r., nr 79, poz. 855, tekst jednolity ze zm.

Westley F., Antadze N. (2010). „Making a difference: Strategies for scaling social innovation for greater impact", Innovation Journal, nr 15 (2).

Wiktorska-Święcka A. (2009). „Zaangażowanie wolontarystyczne a perspektywy rozwoju lokalnego na przykładzie Wrocławia", w: Bokajło W., Wiktorska-Święcka A. (red.), Closer to citizens. Wyzwania dla polskiej demokracji w Unii Europejskiej. Wrocław: Oficyna Wydawnicza ATUT.

Wiktorska-Święcka A. (2011). „Corporate citizenship jako koncepcja włączania działań społecznie odpowiedzialnych do strategii przedsiębiorstwa", w: Karaszewski R., Karwacka M., Paluszek A. (red.), Społeczna odpowiedzialność biznesu. Perspektywy i kierunki rozwoju. Toruń: Wydawnictwo Naukowe Uniwersytetu Mikołaja Kopernika.

Wiktorska-Święcka A., Moroń D., Klimowicz M. (2015). Zarządzanie innowacjami społecznymi. Trendy, perspektywy, wyzwania. Warszawa: Difin.

\section{Social economy entities in the process of managing social innovation}

Summary: Social changes, needs of individuals and families, and escalating social problems trigger the necessity to seek innovative solutions that will bring social benefits more effectively and will meet the needs of people and solve social problems. Social innovation - new solutions, generated and implemented very often by the social sector entities - has become an expression of social responsibility and brings positive results at both micro- and macro-social level. The aim of this article is to present the model of social innovation management in which social sector, included the social economy entities, plays the central role. The article uses the method of desk research, with the analysis of EU documents, source materials and legal acts. The conduct research shows a variety of approaches to social innovation and their differences from other types of innovation. The specific lifecycle of social innovation requires a specific approach to social innovation management. In this context it should be noted that the social economy entities, which as structures are created voluntarily, from the bottom up and regardless of the public authorities, have great potential in the implementation of innovative solutions.

Keywords: social innovation, social innovation lifecycle, social economy entities, managing social innovation.

\section{Prawa autorskie i licencja / Copyright and License}

Artykuł opublikowano na licencji Creative Commons

Uznanie autorstwa - Użycie niekomercyjne - Bez utworów zależnych 3.0 Polska http://creativecommons.org/licenses/by-nc-nd/3.0/pl/

This article is published under the terms of the Creative Commons Attribution - NonCommercial - NoDerivs (CC BY-NC-ND 3.0) License

http://creativecommons.org/licenses/by-nc-nd/3.0/ 